\title{
Learning About Schools in Development
}

\author{
Charles Kenny ${ }^{1}$
}

\section{Introduction}

This paper briefly discusses a number of links in the chain between school construction and improvements in the quality of life -between construction and enrollment, between enrollment and learning, and between schooling and both economic growth and health outcomes. Given what is suggested by the evidence regarding strength of those links, it asks 'is education for all a good idea?' and 'can we improve the quality of education?' While it suggests the answer to these two questions is 'yes,' that is dependent at the least on a significant, potentially politically complicated, focus on the question of quality.

\section{Does More Schools = More Students?}

A lot of schools have been built over the last fifty years --and a lot more people are in school. In 1950, global average enrollment levels were 47 percent. $^{2}$ By 2002, global net primary enrollment was around 87 percent, with a little under one half of the World's countries having achieved universal enrollment levels. ${ }^{3}$ The number of years the average adult worldwide has spent in school has increased from around two years in 1900 to above seven years by the end of the Century, and rates of growth have been far faster in countries previously the furthest behind. ${ }^{4}$

And countries need more schools not just to expand enrollments, but as importantly to keep up with expanding populations. East Asia's population has increased from 1.3 billion to 3.7 billion people 1950-2008 -it is hard to imagine that could have happened alongside dramatically rising school enrollments without a lot of new classrooms being built.

Nonetheless, the relationship between the proportion of kids in school and the number of schools being constructed is more complex than one might expect. Some countries have managed particularly rapid increases in enrollment rates when pent-up demand was satisfied by a new regime which built lots of classrooms or reduced school fees. This was the case in the postcolonial period in a number of countries, for example, or more recently when Uganda introduced

\footnotetext{
${ }^{1}$ charlesjkenny@gmail.com

${ }^{2}$ Benavot and Riddle, 1988

${ }^{3}$ World Bank, 2007. Note the World Bank figure and the Benavot and Riddle figures do not measure enrollment in the same way, see Kenny, 2008c, for a discussion.

${ }^{4}$ Based on data from Morrisson and Murtin, 2008 -this and following are unweighted statistics.
} 
free schooling in 1997. But often, the number of classrooms really isn't the major factor in determining the number of students enrolled. For example, Deon Filmer of the World Bank looked at enrollment rates of children in 21 developing countries to see if children who lived closer to schools were more likely to attend. At the time, average school enrollment in the rural areas of the study countries was 50 percent. He estimated that if every rural household was right next door to a school, this would increase enrollments by three percentage points, to 53 percent. $^{5}$

If not more schools, then what? Consistent evidence that parents who went to school are far more likely to send their kids to schools (and more likely to make them learn) suggests the importance of the demand side to education. ${ }^{6}$ And evidence of these demand-side factors is also clear when you ask parents why their kids aren't in school. In Burkina Faso and Pakistan, for example, surveys of poor people revealed a widespread feeling that educating girls made them less attractive marriage prospects. They would be unsatisfied with their marriage options and less skilled at housework. Some interviewees in Burkina Faso went so far as to argue that education was the surest way for a girl to end up a prostitute. ${ }^{7}$ Such attitudes help to account for a primary completion rate for girls that is 20 percent below the male completion rate in both countries. $^{8}$

The importance of demand for education -rather than government funding, or different rates of school construction - also helps to explain why growth rates in education enrollment have been similar in countries rich and poor, slow growing and miracle pace alike. Michael Clemens of the Center for Global Development describes an s-curve of progress which applies to primary enrollments across countries and time. Slow initial progress in expanding enrolments from very low levels in the first thirty years of the transition towards universal education is followed by rapid progress towards ubiquity. This slows once again as countries reach towards 100 percent enrollment rates. This transition suggests that a country which reaches 50 percent net enrollment today will reach 70 percent enrolment after 22 years and 90 percent after 58 years. ${ }^{9}$ Clemens finds that around ninety percent of the variation in net primary enrollment in all countries for the postwar period can be accounted for by this common global pattern of transition. That leaves a maximum of ten percent of differences across time and countries to be explained by economic growth rates or differing education policies. Again, this suggests that the diffusion of demand for educational services has the key role in explaining outcomes - not supply factors like school construction, which varied considerably across countries. ${ }^{10}$

\footnotetext{
${ }^{5}$ Filmer, 2004

${ }^{6}$ Andrabi, Das and Khwaja, 2009

${ }^{7}$ Narayan et. al. 2000

${ }^{8}$ World Bank, 2009

${ }^{9}$ Clemens, 2004

${ }^{10}$ Clemens does report a secondary influence of income levels on the speed of the education transition, and notes that numerous studies suggest wealthier parents are more likely to send their children to school.
} 
Clemens does note some countries that appear to be exceptions to the rule of steady but unspectacular progress in raising enrollments. But after examining each one in turn he argues that the involved countries were frequently small, didn't have accurate data on enrollments, saw economic booms or an end to prior decades of depressed enrollment and/or were "willing to accept a debacle" in terms of the impact on the amount of attention that each child receives from quality teachers.

\section{Will Kids Turn Up if You Pay Them?}

Having said that, paying parents to enroll their kids appears a potentially powerful tool to get over the demand issue. Mexico's Programa de Educacion, Salud y Alimentacion (PROGRESA), for example, provides cash to mothers in return for child school attendance. An early evaluation found that girls' secondary enrollment increased by 15 percent, and boys' enrollment by seven percent thanks to the program. PROGRESA even increased enrollment rates amongst families who weren't getting a payment --being in a village where more children were going to school created an increased social pressure to enroll. ${ }^{11}$

Conditional cash transfers to promote school attendance have also met with success in Cambodia, Bangladesh, Colombia, Pakistan, Nicaragua, Kenya, Honduras and Brazil. In Cambodia, the payments were focused on girls in the lower secondary school system. Families were awarded a scholarship of $\$ 45$ for each of three years their girl stayed in the lower secondary system maintaining a passing grade. Even this small sum -about two percent of the median household's income - had a dramatic effect. A World Bank study found that absent the program, less than twenty percent of girls from the poorest tenth of families in a region were enrolled in school, compared to above sixty percent for the richest tenth of households. For scholarship recipient families, enrollment rates for girls were above eighty percent for all income levels indeed slightly higher amongst the poorest families than amongst the richest. ${ }^{12}$

To add to the incentive to attend school, some countries have tried paying for uniforms. In countries including India, Bangladesh, Moldova, Armenia and Georgia, for example, interviewed parents spoke of children being so embarrassed by their clothing that they refused to go to school. ${ }^{13}$ Again, in Kenya, while there is no requirement to wear a uniform in schools, nonetheless there is significant social pressure to do so. ${ }^{14}$ A series of child sponsorship programs in rural Kenya since 1995 provided free textbooks and uniforms to students as well as

\footnotetext{
${ }^{11}$ Holla and Kremer, 2008

${ }^{12}$ Filmer and Schady, 2008

${ }^{13}$ Narayan et al, 2000

${ }^{14}$ And emphasizing the close links between education and health outcomes, the free uniform program in Kenya also reduced the rate of teenage childbearing in program schools by ten percent, by making school relatively more attractive than leaving school to have a child -see Holla and Kremer, 2008
} 
constructing classrooms. Of the three interventions, only the uniforms proved effective in keeping children in school.

\section{Will They Learn Anything?}

While stimulating demand for schooling is a great idea in theory, schooling and learning are two notably different things. Indeed, for the great majority of the World's primary-age children (around 87 percent of them), the challenge is no longer staying in school, but actually learning something while there.

The World Bank study of outcomes from the program in Cambodia which provided scholarships to poor female students suggests that while more kids were turning up to school, they weren't necessarily learning anything as a result. Eighteen months after the scholarships were awarded, recipient children did no better on mathematics and vocabulary tests than they would have absent the program. Lower-ability students who wouldn't otherwise have wasted their time went to school in response to the payments - but didn't learn anything when they got there. Similarly, a program in Kenya that dewormed students so they didn't get sick led to increased student attendance rates but had no effect on test scores. ${ }^{15}$ It should be noted that a study of a conditional cash transfer program in Bogota, Colombia did find that the program had a small positive effect on test scores, especially amongst kids who were paid only if they matriculated high school. ${ }^{16}$ It isn't that enrollment programs can't have an impact, but we shouldn't expect much if the school system is weak. And sadly, around the World, a lot of school systems are very weak.

The gap between schooling and learning can be illustrated more broadly by looking at the level of literacy achieved in countries that have dramatically increased school access rates. The net primary enrollment rate in India is 90 percent. And the official literacy rate is 65 percent. But a study of five states in India where 68 percent of respondents classified themselves as literate found that only 38 percent could write their own name correctly and only 12 percent could read a second to third grade text book paragraph with ease. ${ }^{17}$ A lot of these people had been to school but had, apparently, learned little while they were there. Indeed, a recent survey found that of tested Indian students who had completed the lower primary cycle, 31 percent could not read a simple story and 29 percent could not do two-digit math problems.

India is hardly alone. The average reading ability of Indonesian school students is equivalent to that of the lowest seven percent of French students, and the average math ability of Brazilian

\footnotetext{
${ }^{15}$ Kremer and Miguel, 2004

${ }^{16}$ Barrera-Osorio et al 2008

${ }^{17}$ Reading out of the Idiot Box Kothari, Pandey and Chudgar ITID 2, 1, 2004
} 
school students was equal to the abilities of the bottom two percent of Danish students. ${ }^{18}$ In South Africa, 46 percent of kids finish grade nine, but only seven percent acquire a basic literacy in math and science skills as measured on internationally comparable tests. ${ }^{19}$ In the Western Cape, only 2 out of 1,000 sixth graders in predominantly black schools passed a mathematics test at grade level in 2005. ${ }^{20}$ And forty percent of fifteen year old Mexican students fail an internationally comparable reading test passed by all but five percent of students in the average member country of the Organization for Economic Cooperation and Development. ${ }^{21}$

Why aren't kids learning? One significant factor is that there is frequently no-one to teach them. In South Africa, students at one school ended up rioting last year over the fact that their accounting teacher never turned up. Perhaps the only thing surprising about that is they expected things to be different. ${ }^{22}$ Teacher absentee rates are chronic across the system, and the quality of teaching is not that high even when they bother to turn up. One study of South African thirdgrade teachers' literacy, for example, found that the majority of them scored less than 50 percent on a test for sixth graders.

Again, South Africa is hardly unique. Teacher absentee rates are high across the developing world. Eleven percent of teachers are absent on the average day in Peru, 16\% are absent in Bangladesh, 27\% in Uganda and 25\% in India, for example. ${ }^{23}$ And of teachers who bothered showing up in India, a recent survey suggests that only half were actually making any apparent effort to teach. ${ }^{24}$ Added to this, the quality of education that teacher could provide even when they try is often limited by their low level of knowledge. A study in seven southern African countries found that many primary school mathematics teachers possessed only basic numeracy and actually scored lower than their students on the same tests. ${ }^{25}$

In defense of teachers, low student achievement levels are hardly their fault alone. The average amount that low income countries have to spend on buildings and supplies per primary student per year is estimated at about $\$ 12 .^{26}$ And much of that already paltry sum may not actually reach schools. A study from the mid-1990s in Uganda found that schools received $13 \%$ of central government capitation grants for non-salary expenditures, and most schools got nothing (although this number increased dramatically after a campaign to publish data on how much

\footnotetext{
${ }^{18}$ Filmer et. al., 2006

${ }^{19}$ Hanushek and Woessmann, 2008

${ }^{20}$ http://www.nytimes.com/2009/09/20/world/africa/20safrica.html?_r=2\&sq=south\%20africa\%20teacher\&st=cse\&s $\mathrm{cp}=1 \&$ pagewanted $=$ all

${ }^{21}$ Filmer et. al., 2006

${ }^{22}$ http://www.nytimes.com/2009/09/20/world/africa/20safrica.html?_r=2\&sq=south\%20africa\%20teacher\&st=cse\&s $\mathrm{cp}=1 \&$ pagewanted $=$ all

${ }^{23}$ Rogers and Vegas, 2009

${ }^{24}$ Kremer et. Al., 2005

${ }^{25}$ UNESCO, 2005

${ }^{26}$ Adkins, 1999
} 
schools should have received). ${ }^{27}$ That doesn't pay for many textbooks --or even much in the way of basic maintenance.

Beyond limited resources, a number of students who attend school are undernourished and unhealthy -conditions that are related to poor performance. ${ }^{28}$ And kids that work after school, who have to travel some distance to class, or whose parents are illiterate face significant disadvantages in learning. For a range of reasons, then, putting kids into classrooms doesn't necessarily translate into putting knowledge into kids.

\section{Is More Schooling the Secret to Economic Growth?}

A huge number of studies covering different countries and different time frames find that people who have been in primary or secondary school earn more on average than the un-schooled, and those that have been to university earn more than those who have only been to high school. According to estimates made by researchers at the World Bank, a year of extra education is associated with earning ten percent more in Argentina, 12 percent more in China, or seven percent more in Ghana, for example. ${ }^{29}$ It is a short step to assuming that a more educated population will be richer as a whole.

Nonetheless, the gap between schooling and learning might give pause to assuming a close relationship between schooling and economic performance. And if schooling was so good for the economy you'd expect the dramatic catch up in enrollments we've seen by even the poorest and most desperate of countries towards enrollment levels in the rich world over the last fifty years would have been a source of considerable income convergence between the two. No such luck -if anything, the world has seen income divergence over the last half century. ${ }^{30}$

And you would also have expected global average growth to have accelerated under the influence of all that extra schooling. But growth rates have slowed down over that time. Sub Saharan Africa has seen gross primary enrollment levels climb from below 35\% to above 95\% 1960-2005. ${ }^{31}$ Sadly, the region's average growth rates have declined over that period. Between 1960 and 1980, Sub Saharan Africa's GDP per capita increased 36\%. Between 1980 and 2007, it climbed a mere $4 \% .{ }^{32}$ Using a range of approaches to uncover a link, Lant Pritchett asked

\footnotetext{
${ }^{27}$ Reinikka and Svensson, 2004

${ }^{28}$ Kremer and Miguel, 2004

${ }^{29}$ Psacharopoulos and Patrinos, 2002

${ }^{30}$ Pritchett, 1997

${ }^{31}$ Easterly, 2009

${ }^{32}$ Calculated using real GDP from World Bank 2009.
} 
"Where has all the education gone" in a paper that looked for -and failed to find-- any significant relationship between schooling and economic growth around the world. ${ }^{33}$

Pritchett argued that there were three possible explanations: education had expanded fast enough that the supply of educated students outstripped demand; that educated workers were in lucrative jobs that had little social value (hedge fund manager, TV news pundit); or that kids weren't actually learning anything in school. As we've seen, educated people keep on earning more, so a simple version of the supply and demand model doesn't seem to work as an explanation. And while casual empiricism suggests a lot of pretty useless jobs pay well, you would have to think that most jobs were economically useless in many countries to believe that the explanation rests solely on a market failure related to salaries. But we have already seen considerable evidence for the third explanation -that kids just aren't learning anything. ${ }^{34}$

The complex link between our measures of investment in 'human capital' -schooling-- and growth can be illustrated by comparison with what we've learned about the link between investments in physical capital and growth. In the 1950s, the consensus amongst economists was that low investment was the reason that poor counties were poor. If only the newly independent states of Africa spent more on factories and roads, they would become rich. Sixty years later, we have a considerably nuanced view of the power of investment to encourage economic growth. Not only does the return to investment depend crucially on the environment in which it is made, but a lot of activities recorded as 'investment' in the national accounts might be better labeled otherwise. Think the Ajoukuta steel plant in Nigeria. It cost upwards of $\$ 4$ billion dollars 'investment' to complete but has never produced to near its designed capacity. Some reports suggest that US $\$ 2$ billion of the 'investment costs' had been siphoned off from the project in corrupt payments. ${ }^{35}$ At the national level, Bill Easterly notes that if "Zambia had converted all the aid it received since 1960 to investment and all of that investment to growth" following the traditional investment to growth model, "it would have had a per capita GDP of about $\$ 20,000$ by the early 1990s. Instead, Zambia's per capita GDP in the early 1990s was lower than it had been in 1960 , hovering under $\$ 500 .{ }^{\prime 36}$

What is true of investment in physical capital is as true of educational investment. All too often, we have constructed schools, hired teachers, and enrolled students only to have them sit in classrooms absent the textbooks, absent chalk, absent the teacher -and absent any incentive to try. Economists usually measure stocks of 'human capital' as years of education per person or worker in the economy. More recently they have begun adjusting human capital estimates to allow for quality as measured by scores on internationally comparable tests. Given the issues with 'educational investment' around the world, it is unsurprising that when they adjust for the

\footnotetext{
${ }^{33}$ Pritchett, 2001

${ }^{34}$ See also Temple, 2001

${ }^{35}$ Pritchett, 1999

${ }^{36}$ Easterly, 2003
} 
quality of education, stocks of human capital in developing countries look a lot smaller. Human capital stocks in India unadjusted for quality were 45 percent of US human capital stocks in 1988. If you adjust for quality, the figure might be closer to 25 percent. $^{37}$

But even in countries that do manage to teach kids something that ups their test scores, there is still some debate over why more educated people earn more money. Is it because of what they have learned, or the fact that they have demonstrated they could learn, or the fact that they got into school in the first place? It may be that much of what the students learn really does have limited economic value. Knowing the kings of England and/or fights historical in order categorical may, really, have little role in fostering growth. And perhaps learning how to take tests might be a distraction from absorbing useful knowledge.

A recent study in Italy found that test scores had a significant impact on the earnings of employees but none on the earnings of the self employed. ${ }^{38}$ Perhaps Pink Floyd was right, and the value of education is to teach you how to be a better brick in the wall -a useful skill for the company man, less valuable to the entrepreneur. Or perhaps education was acting purely as a signal to employers - the actual stuff that students learned in Italian schools was of no intrinsic financial value. Think Bill Gates, who got into Harvard, but didn't finish his studies. The signal was right --but the education wasn't necessary for his success. Similar results have been found in a range of other developed and developing countries. ${ }^{39}$ In Ghana, for example, a survey of firms found that better educated workers got paid more whatever their performance level and more education didn't correlate with better performance once cognitive ability was taken into account. $^{40}$

This is not to say a greater appreciation of Dante's poetry or the wonders of the universe isn't of immense personal and social value in its own right -nor that basic literacy and numeracy aren't incredible valuable skills in both economic and social terms. The above studies surely go too far in suggesting there might be no impact of education systems and what kids learn in school beyond signaling - which, by the way, is a useful function in and of itself. Nonetheless, these findings do suggest some potential problems regarding the link between learning and economic performance.

Some good news is that a number of recent studies suggest that education does have an impact on economic growth if we adjust for quality. In other words, countries that actually manage to educate lots of kids appear to grow faster. ${ }^{41}$ But a link between education and economic growth may reflect the signaling power of education at the national level as much as a link between education and income at the individual level might. Countries that actually manage to educate

\footnotetext{
${ }^{37}$ Soto, 2006

${ }^{38}$ Castagnetti, Chelli, and Rosti, 2005

${ }^{39}$ Koch and Ntege 2008, Feng LiangXiaohao and Morgan, 2009

${ }^{40}$ Serneels, 2008

${ }^{41}$ Soto, 2006, Hanushek and Woessmann, 2008
} 
kids can probably do much else aside -effectively police cities, maybe, or regulate banks, or build roads. So, the debate is far from closed even on the causal impact of learning and economic growth, let alone schooling.

Of course, over the long term, education (where it actually happens) might actually have a considerable development impact beyond teaching directly relevant 'cognitive skills.' Not least, education can teach a common language and instill a sense of national solidarity. At the time of the French Revolution there were over three hundred dialects spoken in the country, for example. An explicit goal of the highly centralized education system that emerged after the Revolution was to help foster a national identity. By 1919, it was a commonplace that "Practically all modern nations are awake to the fact that education is the most potent means in the development of the essentials of nationality" according to a course instructor in New York who had designed an entire syllabus for a course on Democracy and Nationalism in Education. ${ }^{42}$ Similar sentiments underpin the education policies of numerous countries to this day. But if that is the link (and even if it works), we may have to wait some time to see a payback to expanded education in developing countries.

\section{Is Schooling is Good for Your Health?}

It is one of the strongest results in decades of research into the causes of lower infant and child mortality -mothers who go to school have healthier kids. ${ }^{43}$ But the study of the Cambodian conditional cash transfer program we looked at earlier found that amongst the many things that children who attended school because of the program weren't learning was anything about health outcomes. Why would mothers who sat through classes with teachers who didn't teach, or who lacked textbooks, or who, in many countries, weren't even meant to learn about reproductive and child health, necessarily see better health outcomes for their children? This does suggest the need to look further at what causes what when it comes to both health and education outcomes.

At the least, the relationship between education and health operates in both directions. We have seen that kids who got deworming treatments in Kenya are more likely to stay in school, for example -even if in that case they don't apparently learn anything more as a result. ${ }^{44}$ And Gary Becker of Chicago suggests that if kids are more likely to survive childhood, it makes much more sense for parents to invest in their education. ${ }^{45}$

\footnotetext{
${ }^{42}$ The course was for the Teachers' College at Columbia University, the instructor was Edward Resiner.

${ }^{43}$ See Kenny and Casabonne, 2008, for a partial review.

${ }^{44}$ Kremer and Miguel, 2004

${ }^{45}$ Becker and Lewis, 1973. Similarly, while there is evidence of a causal relationship between the two( Osili and Long 2007) work in South Asia suggests that fertility is declining amongst the educated and uneducated alike, and the relationship between levels of education and levels of fertility is complex, at the least (Jeffey and Basu, 1996).
} 
In addition, and once again, perhaps schooling is signaling something. Michael Clemens' analysis of the transition to universal enrollment suggest the importance of the demand side to education -and so the link between cultural change and enrollment levels. This suggests schooling may be a proxy measure for such cultural change -especially with regard to girls' education. The choice to send girls to school might indicate a change in the power relations within the household in which women -and their opinions - matter more. This change in power relations may matter more to health outcomes than the education that girls get in the classroom.

Some independent evidence of the importance of the idea of equality rather than what kids learn in school comes from studies of the impact of television on measures of gender equality and girls schooling. Robert Jensen and Emily Oster studied the introduction of cable and satellite services in villages in India, which allowed households to watch a range of soaps starring strong women characters with few (educated) kids and who had control over money. Rollout of cable and satellite is associated with higher girls' school enrolment rates, increased female autonomy and lower fertility. ${ }^{46}$ Within two years of introduction, between 45 and 70 percent of the difference between urban and rural areas on these measures disappears. If changing attitudes in the household are in fact the most important factor in determining changes in behavior, which then improve health outcomes, sending a five year old off to sit in a classroom is at best an indirect way to accomplish that.

Eliot and Dean Jamison, along with Eric Hanushek at the NBER argue that countries whose school children do better on education test scores see more rapid reductions in infant mortality. ${ }^{47}$ But this result is subject to the same type of concerns about the link between education quality and income growth -countries that actually manage to teach kids in school might also do a better job of vaccinating them, or providing them with clean water-factors not allowed for in the analysis. Still, it is a more plausible story that actually learning things leads to better childcare and health practices rather than the assumption that merely sitting in a classroom somehow magically makes you a better parent.

\section{Is Education for All A Good Idea?}

It is a popular idea, for sure. The World Declaration on Education for All, adopted by 155 countries in a conference in Jomtien, Thailand, in 1990 stated that "Primary education must be universal" and "ensure... the basic learning needs of all children." Michael Clemens notes that it was not the first international conference to commit to universal education -these date back to the 1960s. Nor was it the last -not least, the Millennium Development Goals reaffirmed 2015 as a target date for all kids to finish primary school.

\footnotetext{
${ }^{46}$ Jensen and Oster, 2007

${ }^{47}$ Jasmison, Jamison and Hanushek, 2006
} 
Notably unlike the Millennium Development Goal target for education, however, which focused purely on universal primary completion, the World Declaration on Education for All -and many of its predecessors-- emphasized basic education services "of quality." It also noted that successful basic education needed students in a fit state to learn and so that they had "the nutrition, health care, and general physical and emotional support they need in order to participate actively in and benefit from their education." Perhaps universal childcare for all kids five and above is worth pursuing, but universal primary education which actually involves students learning something is surely an even better goal.

At the same time, the fastest way to achieve quality education may not be to attempt universal access first, followed by quality second. First, reaching universal access isn't just about supply as we haves seen - it is about demand. Second, even if it turns out that there is 'latent demand' for education which allows for a rapid hike in enrollment figures, there is growing evidence that moving too rapidly towards access may have a significant negative impact on quality. Malawi's decade-old, underfinanced and largely unplanned experiment in moving almost overnight to universal primary education is generally regarded as a failure, according to Clemens. The number of children in a first-grade class averages 100. Four out of 10 first-graders repeat the year. Children's achievement scores are among the lowest in Africa.

Similarly, the free primary schooling initiative launched in Kenya in 2003 saw more than a million additional children showing up for public schooling when the government abolished fees. The explosion in enrollments has put enormous pressure on an already overburdened education system. ${ }^{48}$ Furthermore, the move to free education may have done little to increase total enrollments, merely moving a lot of children from private schools to public schools. All this quite possibly at the cost of average quality, given that privately schooled children in other parts of Africa score better than their publicly-schooled counterparts on math and English tests. ${ }^{49}$

And with regard to using conditional cash transfers to further stimulate demand, it is a question worthy of consideration: how high are the economic and social returns to financial inducements to stay in school if they encourage students to attend classes where they may learn so little in part because of paltry expenditure on supplies? Even if school systems were to pay only $\$ 45$ per year per student in incentives for them to attend, that's still nearly four times what many countries are spending on buildings, books, chalk and paper per student -and many multiples of what many schools are actually receiving for non-salary costs. Ensuring quality surely should come before incentivizing quantity in these cases.

Education for All focuses attention on an important issue -but a complex one. Every kid should be in school, and every kid should learn something when they get there. But getting to that state is not an easy task. Building schools is probably the simplest part of it, with hiring teachers a

\footnotetext{
${ }^{48}$ Clemens, 2004

49 Tooley, 2005
} 
close second. A lot of poor and poorly governed countries have managed to do this. Getting children to learn appears to be far harder.

\section{Can We Improve the Quality of Education?}

Worldwide, arguments rage over the best way to ensure kids learn in school. That they continue to do so suggests there is probably no one-size-fits-all solution. Any number of attempts to improve the quality of education have failed. ${ }^{50}$ Indiscriminately throwing money at the problem certainly seems an inadequate response -the link between expenditures on schooling and enrollments or scores on internationally comparable tests is very weak. ${ }^{51}$ There are a number good reasons why. Spending may not reach the schools, as we have seen. Or it might substitute for private expenditures given the strong demand-side element to education -indeed, a study in Zambia suggest that public spending on education substituted one-to-one for parental schooling expenditures. $^{52}$ Or perhaps spending reaches schools but has little impact-surveys in India suggest that more highly paid (and more senior) teachers are just as likely to be bunking off work as their junior colleagues. ${ }^{53}$

Two oft-mentioned approaches to overcome this problem are decentralization to increase parent power and pay for performance for teachers and administrators. Both are potentially exciting approaches, but also illustrate the problem of assuming one approach will work everywhere.

Starting with decentralization of power, parents who know that their opinions will be taken into account are more likely to provide oversight of school performance. It is a repeated finding in the literature that decentralization of school management down to the individual school level improves outcomes because parents are more likely to become involved in the schooling process. ${ }^{54}$ Having said that, a randomized study from education in India suggests that despite considerable de jure powers of oversight by village education committees in Uttar Pradesh and efforts to increase interest in and awareness of schooling quality and the role of village education committees, outcomes remain poor and village education committees dysfunctional. ${ }^{55}$ The authors of the education study conclude that large-scale oversight mechanisms work best when stakeholders can directly and easily observe problems -which they couldn't in this case, despite the fact many in the oversight committees were parents of kids in the schools they were overseeing.

\footnotetext{
${ }^{50}$ Hanushek and Woessmann, 2008

${ }^{51}$ Hanushek and Kimko, 2000, Clemens, 2004

${ }^{52}$ Das et al. 2003

${ }^{53}$ Kremer et. Al., 2005

${ }^{54}$ Di Gropello, 2004

${ }^{55}$ Banerjee et al 2008.
} 
With regard to teacher incentives, a randomized study supported by the World Bank looked at the impact of providing additional resources to primary schools in the Indian state of Andhra Pradesh. Some schools were given block grants to spend on books, chalk and other materials. Other schools were given money to use as bonuses to primary school teachers whose students performed better on math and language tests. Spending more on materials had some impact, but rupee for rupee, the impact of bonuses was three times as large. Indeed, the bonus system even improved test scores on tests in other subjects where no teacher incentive was attached. ${ }^{56}$

Similarly, in an experiment led by Esther Duflo of MIT and carried out in 57 Indian schools, a teacher's daily attendance was verified through photographs with time and date stamps, and his salary was made dependent on his attendance. The teacher absence rate dropped from 42 percent to 21 percent as a result of the incentives. The program also improved test scores in the schools. ${ }^{57}$ Nonetheless, in Kenya, teacher performance incentives related to test scores increased student scores in the short run as teachers figured out how to manipulate scores, but did not increase teacher attendance, the quality of pedagogy or homework assignment. ${ }^{58}$

Perhaps a more direct approach might work - paying the kids themselves for improved perfromance. A number of US school districts are evaluating such approaches. A more subtle variant might use peer pressure to achieve the same result. Michael Kremer argues that one way to improve the quality of boy's education is to give scholarships to girls who do well in school. This improves the test scores of boys as well because they compete to equal the improved test scores of their female classmates. ${ }^{59}$ Having said that, surely this once again is no panacea especially in cases where whatever the motivation of the students, teachers have no incentive to teach.

Finally, approaches to improving quality are often politically complex, and may face opposition from powerful lobbies. Regarding South Africa, "we have the highest level of teacher unionization in the world, but their focus is on rights, not responsibilities," Mamphela Ramphele, former vice chancellor of the University of Cape Town, complained in a recent speech. ${ }^{60}$ Even if introduced, reforms that are designed to improve incentives may be manipulated so that they can be gamed -apparently the case in Kenya. Behind the more rapid spread of schools than of learning lies a story of the differing political economies involved.

\section{Conclusion}

\footnotetext{
${ }^{56}$ Muralidharan and Sundararaman, 2009

${ }^{57}$ Duflo et al, 2008

${ }^{58}$ Glewwe et al. 2003

${ }^{59}$ Kremer et. al. 2004

${ }^{60}$ http://www.nytimes.com/2009/09/20/world/africa/20safrica.html?_r=2\&sq=south\%20africa\%20teacher\&st=cse\&s $\mathrm{cp}=1 \&$ pagewanted $=$ all
} 
It is hardly a surprise that there is more to 'human capital' than putting kids in a school. J.S. Mill had learned Greek by the age of three, had read all of Herodotus by age eight, had completed most of the famous Latin texts by age ten and had a nervous breakdown by age twenty all absent the benefits of attending a school. We have seen that Bill Gates dropped out of Harvard but this was apparently no barrier to a reasonably successful career.

While putting more kids in school is a sign of development progress, this is in many cases as much because of what it says about how society has changed than what it says about what children will learn while there. Unlike vaccinating every child for measles, putting every kid in school doesn't in and of itself guarantee improved quality of life. But, if the environment is right, children can learn lots of useful stuff in school, with considerable economic and social returns attached.

And even if decentralization and teacher, parent and student incentives are unlikely to be universal cure alls in and of themselves, they do show some promise when it comes to improving outcomes. There are ways to improve the returns to both public and private investment in education, then -and we should grasp them. This not only on the grounds that it might improve a country's economic performance, but based on the certainty that it will improve the quality of life of students. 


\section{Bibliography}

Adkins, D., 1999. Cost and finance. in: Dock, A., Helwig, J. (Eds.), Interactive Radio Instruction: Impact Sustainability and Future Directions. The World Bank, Washington, DC.

Andrabi, T., J. Das and A. Khwaja (2009) What Did You Do All Day? Maternal Education and Child Outcomes, World Bank Policy Research Working Paper 5143.

Barrera-Osorio, F. M. Bertrand and L. Linden, Leigh and F. Perez-Calle, ( 2008). Conditional cash transfers in education : design features, peer and sibling effects evidence from a randomized experiment in Colombia, World Bank Policy Research Working Paper 4580.

Becker, G. and H. Lewis (1973) On the Interaction Between the Quantity and Quality of Children Journal of Political Economy 81 S279-S288.

Castagnetti, C., F. Chelli, and L. Rosti, (2005) Educational Performance as Signalling Device:

Evidence from Italy. Economics Bulletin, Vol. 9, No. 4

Das, Jishnu, Stefan Dercon, James Habyarimana, and Pramila Krishnan (2003), .When Can School

Inputs Improve Test Scores?.forthcoming Policy ResearchWorking Paper, Development Economics, World Bank.

Duflo, E, R. Hanna, and S. Ryan (2008), Monitoring Works: Getting Teachers to Come to School CEPR Discussion Paper No. DP6682

Easterly, W. (1999) The ghost of financing gap: Testing the growth model used in the international financial institutions, Journal of Development Economics 60, 2.

Easterly, W. (2009) How the Millennium Development Goals are Unfair to Africa, World Development 37, 1.

Feng Liang, L., D. Xiaohao and W. Morgan (2009) Higher Education and the starting wages of graduates in China International Journal of Educational Development, Volume 29, Issue 4,

Filmer, D. and N. Schady, (2009), School Enrollment, Selection and Test Scores World Bank Policy Research Working Paper Series 4998

Glewwe, Paul, Nauman Ilias, Michael Kremer (2003), .Teacher Incentives.Working Paper 9671, National Bureau of Economic Research

Hanushek, E. and D. Kimko (2000) Schooling, Labor Force Quality and the Growth of Nations, American Economic Review 90, 5, 1184-1208.

Hanushek, E. and L. Woessmann (2008) The Role of Cognitive Skills in Economic Development Journal of Economic Literature 46, 3.

Osili, U. and B. Long (2007) Does Female Schooling Reduce Fertility? Evidence from Nigeria, NBER Working Paper 13070 
Jamison, E., D. Jamison and E. Hanushek (2006) The Effects of Education Quality on Income Growth and Mortality Decline NBER Working Paper 12652

Jeffey, R. and A. Basu (1996) Girl's Schooling, Women's Autonomy, and Fertility Change in South Asia, Sage, New Delhi, India.

Kenny, C. (2006) Overselling the Web? Development and the Internet, Boulder: Lynne Rienner

Kenny, C. and U. Casabonne (2008) The Best Things in Life are (Nearly) Free: Technology, Ideas and the Global Quality of Life, mimeo, Center for Global Development.

Koch S. and S Ntege (2008) Returns to Schooling: Skill Accumulation or Information Revelation? University of Pretoria Working Paper: 2008-12

Kremer, M and E. Miguel (2004) Worms: Identifying Impacts on Education and Health in the Presence of Treatment Externalities, Econometrica 72, 1.

Kremer, M., N. Chaudhury, F. Rogers, K. Muralidharan and J. Hammer (2005) Teacher Absence in India: A Snapshot, Journal of the European Economic Association 3:2-3

Muralidharan, K. and V. Sundararaman (2009) Teacher Performance Pay: Experimental Evidence from India, NBER Working Paper 15323

Oxfam (2000) Education Now: Breaking the Cycle of Poverty, Oxford: Oxfam

Pritchett, L. (1997) Divergence, Big Time, The Journal of Economic Perspectives, 11, 3, 3-17

Pritchett, L. (1999) The Tyranny of Concepts: CUDIE (Cumulated, Depreciated Investment Effort) Is Not Capital World Bank Policy Research Working Paper No. 2341

Psacharopoulos, G. and H. Patrinos (2002) Returns to Investment in Education, A Further Update World Bank Policy Research Working Paper No. 2881

Reinikka, R. and J. Svensson (2004), Local Capture: Evidence from a Central Government Transfer Program in Uganda, The Quarterly Journal of Economics, vol. 119 (2): 679-705.

Serneels, P. (2008) Human capital revisited: The role of experience and education when controlling for performance and cognitive skills Labour Economics Volume 15, Issue 6,

Soto, M (2006) The Causal Effect of Education on Aggregate Income, mimeo, Instituto de Analisis Economico, Barcelona.

Temple, J (2001) Generalizations That Aren't? Evidence on Education and Growth European Economic Review 45, 4-6.

World Bank (2009) World Development Indicators Washington DC: World Bank 